Cahiers du MONDE RUSSE

\section{Cahiers du monde russe}

Russie - Empire russe - Union soviétique et États indépendants

$57 / 1 \mid 2016$

Terres, sols et peuples : expertise agricole et pouvoir (xixe - xxe siècles)

\title{
Agrarian Experts And Social Justice
}

Land allotment norms in revolution and Civil War, 1917-1920

Experts agricoles et justice sociale: les normes gouvernant la répartition des terres pendant la révolution et la guerre civile, 1917-1920

\section{David Darrow}

\section{OpenEdition}

\section{Journals}

\section{Electronic version}

URL: http://journals.openedition.org/monderusse/8330

DOI: $10.4000 /$ monderusse. 8330

ISSN: 1777-5388

\section{Publisher}

Éditions de l'EHESS

\section{Printed version}

Date of publication: 1 January 2016

Number of pages: $55-80$

ISBN: 978-2-7132-2540-6

ISSN: $1252-6576$

\section{Electronic reference}

David Darrow, «Agrarian Experts And Social Justice », Cahiers du monde russe [Online], 57/1 | 2016, Online since 01 January 2019, Connection on 23 April 2019. URL : http://journals.openedition.org/ monderusse/8330; DOI : 10.4000/monderusse.8330

This text was automatically generated on 23 April 2019

(c) École des hautes études en sciences sociales 


\title{
Agrarian Experts And Social Justice
}

\author{
Land allotment norms in revolution and Civil War, 1917-1920 \\ Experts agricoles et justice sociale : les normes gouvernant la répartition des \\ terres pendant la révolution et la guerre civile, 1917-1920
}

\section{David Darrow}

I would like to thank Katja Bruisch and Klaus Gestwa for their work to bring this article to publication, beginning with a conference on the topic of environmental and agrarian knowledge at the German Historical Institute in Moscow in March 2014. Their comments, as well as those of the journal editors and anonymous reviewers, have been invaluable to the revision process, and have made this a better piece of work. Any remaining deficiencies are my own responsibility. Finally, I would also like to thank the University of Dayton Department of History and College of Arts and Sciences for funding my research, David McDonald and Frank Wcislo for reading drafts at various stages, and James Vogel for his editorial assistance.

1 Of the popular demands of 1917-Bread, Land, and Peace-only land was not tied to wartime conditions. Whether expressed as the "land question" (zemel'nyi vopros), "agrarian question" (agrarnyi vopros), "land hunger" (malozemel'ie) or simply as the "insufficient allotment" (nedostatochnyi nadel), the question of land access and the place of the peasantry in the Empire's future economic development dogged the Emperor's ministers from the serf emancipation of 1861 until the old regime's end. The biggest social justice issue in the Russian Empire-the moral question on the minds of imperial subjects from the chancery halls of St. Petersburg to the peasant pastures of Podolsk-was the question of land. The normatized land allotment (nadel) objectified the moral dimension of the land question. With origins as a tool of state agrarian policy dating at least to eighteenth-century statutes on the organization of crown (udel) lands and running through the Kiselev reforms of the state peasantry (1840s-1850s), the normatized land allotment, enshrouded in the moral fervor of Emperor Alexander II's "scenario of power" and his accompanying moniker "Tsar Liberator," emerged from the Emancipation process as a primary symbol of the state's moral commitment to the peasantry's well being. ${ }^{1}$ Between 1861-1917, educated society's interpretation of the Emancipation combined with the state's "meliorative" and tutelage (opeka) approaches to the peasantry 
to create public expectations that the state was obligated to solve the agrarian question by ensuring peasants sufficient access to land (at least the maximum regional land allotment size stipulated by the Emancipation statutes). ${ }^{2}$ Having posed the peasantry's plight as a question, society expected a state answer.

2 This tendency toward, and preference for, state solutions-gosudarstvennost' or "state-mindedness"-represented a tradition with roots in eighteenth-century cameralism and its notion of "public property" and the commonweal. It grew sharper over the nineteenth century as the state positioned itself (with much of educated society's blessing) as the only entity that could preserve stability and international status amidst a sea of parochial interests in a manner that protected the peasantry from the predation of speculators and socialists. ${ }^{3}$ At the same time experts in and out of government gained a greater sense of what technical expertise backed by state power might achieve in terms of modernizing peasants viewed as benighted ("dark"), backward, and in need of perpetual guidance. ${ }^{4}$ Experience on the ground re-ordering territory on the imperial periphery to facilitate migration to Siberia and Central Asia and the continued collection of statistical information, culminating in the massive land organization project known as the Stolypin reforms, revealed common ground in the agendas of state officials and agrarian experts. This reinforced the idea that the state could correct the deficiencies of the Emancipation and fulfill its moral obligation to the peasantry while at the same time converting it into a meaningful contributor to the national economy. ${ }^{5}$

3 The land allotment was a prominent component of all of these programs as well as many of the land reform proposals that emerged in the Duma-a tool for solving the agrarian question by ordering agricultural space. ${ }^{6}$ In the Russian empire this land allotment mentalité defined a moral approach to agrarian reform, especially from 1861 onward, among conservative and liberal state officials, educated society, and the objects of reform -peasants-alike. Indeed, by 1917 one might say that Yaney's "urge to mobilize" was very much an "urge to normatize" and that the allotment of land by norm-far from being a "revival of the intelligentsia legacy" of the old Populists represented the continuation of a general trend in land reform policy that had been nuanced by professionals as they adapted their project to encounters in the field. ${ }^{7}$ Even experts who realized that the solution to the agrarian question rested with intensification argued that granting additional land allotments was the first step toward providing peasant households with the requisite resources for adopting intensive agricultural techniques-that some level of extensification was required to make intensification possible. ${ }^{8}$ There was a consensus that, if managed properly, extensification was a viable part of agrarian reform (although widely differing opinions existed as to the source of additional land). ${ }^{9}$ Even if honored as much in the breach as in its observance, by 1917 experts and other elites (in and out of government service), as well as peasants saw the normatized land allotment as a state entitlement. It was a symbol of the state's moral obligation to the peasantry embodied in the Emancipation that all found wanting and in need of correction. ${ }^{10}$ Agrarian experts could thus solve the Empire's agrarian question by allotting peasant households additional land according to local "norms" derived from the better information that had accumulated since 1861. In other words, the normatized land allotment was not just an exercise in "administrative utopia" or a statist attempt "to impose social change on a people through administrative means." ${ }^{11}$ It was a restoration of the promise of 1861 that peasants, their advocates, and the rest of society had come to expect. The old Regime 
land allotment, the product of servile life, continued to serve as an expression of rational resource management in the name of national economic prosperity and improvement-a rational approach to constructing a new and more productive rural economy in line with previous reform efforts, including those initiated by Stolypin. The land allotment also became the objectification of the post-autocratic state's moral obligation to the peasantry (justice). Allotment norms were a measure of social justice, a technocratic (and thus, supposedly value-neutral) solution to the land question rooted in earlier attempts at land reorganization that met diverse political needs in a fragmented socio-political world. This reflected a broader agrarianism in Russian society-a consensus that the agrarian future would center on the peasantry in close collaboration with agrarian experts (broadly defined) and that it was incumbent on the state to ensure peasant households a "sufficient" endowment of land through allotment of land by norm. ${ }^{12}$

\section{The main land committee and allotment by norm}

Land reform topped the list of expectations that the autocracy's end bequeathed to the Provisional Government. To develop a land reform proposal for consideration by the Constituent Assembly, the Provisional Government created a Main Land Committee (GZK) under the Ministry of Agriculture. The GZK brought together government experts and those generated by society's engagement with the rural economy through both political activism and zemstvo employment. Several of its members, such as Professor A.A. Kaufman, incorporated experience in all three realms. Many members, including the chair, Professor A.S. Posnikov, objected to the Stolypin reforms even though they embraced their goal of increasing peasant productivity. ${ }^{13}$ The GZK sat at the apex of a system of theoretically subordinate land committees on the provincial, district and township levels. All committees were to include local experts (zemstvo agronomists, statisticians, etc.) that the GZK deemed best situated for ascertaining local conditions and collecting data needed to shape agrarian reform and apply it at the local level. ${ }^{14}$ The membership of the land committees intersected with non-governmental professional groups such as the League of Agrarian Reforms (Lig Agrarnykh Reform), and represented most political affiliations from the center-right through the left. Many members were also active in the Petrograd and provincial peasant congresses that convened throughout 1917. These intersections were fraught with political tensions, but also represented and transmitted a common knowledge base derived from academic and administrative fieldwork with the peasant economy, as well as discussions of agrarian reform of the preceding decade. Most, such as N.P. Makarov and N.K. Volkov, had some sort of advanced training in agrarian economics. Based on their experience, there existed a strong consensus that land norms represented the best means by which the agrarian fruits of revolution could be allotted to meet peasant needs, fulfill their revolutionary aspirations, and ensure just land distribution. Revolution and the establishment of the GZK marked a triumph of the experts who, freed from the constraints of the old regime, could now begin to position peasant participants in a single rural economy of smallholders for developmental success. ${ }^{15}$ Everything they had spent their professional lives doing had prepared them for this moment-from zemstvo statistical work to agronomy. As the Socialist Revolutionary (SR) N.Ia. Bykhovskii noted, allotment of land by norm was the first step towards modernizing the agrarian economy (intensification) and giving 10 million landless peasants access to land-the first step in developing the 
peasant labor economy as the foundation of Russia's agricultural future. Land allotments, agrarian improvement and social justice went hand in hand. ${ }^{16}$

5 A number of key issues confronted and divided GZK members. Would peasants become landowners or merely receive use rights? If not the former, what about the fate of the Stolypin separators $?^{{ }^{17}}$ On what terms should the alienation of private land take place? Who should be allotted land-anyone who desires to farm it with their own labor or, given limited resources, only those households currently engaged in farming $?^{18}$ Despite these differences, widespread consensus existed on a number of fronts. First, members saw themselves as experts charged with righting the mistakes of the 1861 Emancipationof correcting the perceived injustice of the past that had been demonstrated by statistical studies and popularized in journal publications since the 1870s but that the old regime had failed to ameliorate. ${ }^{19}$ Second, there was a consensus that, with the exception of model farms and specialized forms of husbandry, all land was now part of single national land fond for allotment to those who worked it. Lands held by various state institutions and private landholders alike would be subject to alienation and redistribution. By extension, most agreed that any "solution" of the land question must be a national one, albeit one that carefully considered local circumstances. Finally, they agreed that the best means of assuring an equal and just redistribution of land throughout the country was by establishing land allotment norms that recognized the particularisms of local economies. The GZK assigned these questions to subcommittees whose membership overlapped extensively with each other and with the League of Agrarian Reforms.

Mindful of the failings-real and imagined-of the 1861 Emancipation, mindful of the role that agricultural professionals had played in exposing them, and committed to creating a national program of land reform aimed at eliminating the problem of insufficient allotments in a just way, the specter of 1861 overshadowed the experts' work as a moral imperative in 1917. As GZK member N.P. Oganovskii noted before the war, the work of Professor Iu.E. Ianson and other experts had discovered by the 1870s "that the greatest causes of the pauperization of the peasant consist in the insufficiency of land allotments, significantly reduced [urezannykh-"cut off"] by the emancipation." ${ }^{20}$ Aware that history would measure their achievements, Oganovskii and his peers did not want to find out twenty years later that their reform had resulted in a redux of "insufficient allotments." The shadow of 1861 appeared in other forms as well. As N. Ozeretskovskii noted, "The very name of these institutions [land committees] reminds us of the time of the reform of 1861 when prior to the emancipation of peasants were established ... a Main Committee... and then 48 provincial committees." From his perspective, pomeshchiki populated these local committees in 1861 and the deficiencies of the Emancipation resulted from their narrow class interests. ${ }^{21}$ The work of the current committees would be guided "by different hands," thus presenting an opportunity to redress these deficiencies in the interests of the people..$^{22}$ Finally, memories of 1861 also hovered over the process in other ways, including early consideration of introducing "peace arbitrators" (mirovyie posredniki ) to perform a similar role in regulating land relations as they had under the Emancipation and in brief explorations of compensating private owners for alienated land with a redemption operation. ${ }^{23}$ As in 1861 , some reformers questioned how alienation would impact state credit institutions given the fact that over half of the land to be alienated as part of the proposed reform carried mortgages. The ghost of the banking crisis that had shaped the 1861 Emancipation still haunted the economy. ${ }^{24}$ 
7 Given developments of the previous decade, particularly efforts by state officials and agronomists to foster intensive cultivation as a means of solving the agrarian question, the fact that reformers framed their work within the context of the Emancipation might seem surprising. Yet, reformers in and out of government had long recognized that agrarian reform-intensification-required land reform first, both in terms of reorganization and in terms of ensuring household access to sufficient land resources. Revolution sharpened the focus on the latter because peasants expected it and because it provided experts the opportunity to create a better material basis for an improved rural economy rooted in peasant agriculture by eliminating the last remaining constraints on conceptualizing all land as a public good. With few data and resources, the 1861 reformers hoped to achieve little more than a peasant perception of improved living conditions. This time, the experts charged with drawing up an agrarian reform proposal were in far better shape from an information standpoint, and saw themselves as poised to establish the material basis for a new agrarian future. As N.Ia. Bykhovskii noted, given the "grandiose" extent of the territory and historical moment, "the land reform must in and of itself be highly grandiose," mindful of its national import while attentive to local needs. ${ }^{25}$ Like their predecessors, these reformers also operated from the assumption that the state should ensure that allotments were sufficient for meeting household needs. In the throes of revolution, the demands of social justice now required that the means by which the state allotted land be perceived as more accurate and more just than those used in 1861.

8 What stands out in this process is the fact that the experts refashioned the allotment of land by norm used in 1861, incorporating new information while attempting to incorporate measures of both consumption and labor usage, and did so with little internal dissention. Some have portrayed this as a sign of the experts' failure to achieve their own Progressivist agenda of the previous decade-a revival of a Populist "intelligentsia legacy" from the nineteenth century-or as simply being out-run by events. ${ }^{26}$ Couched in these terms, land norms certainly were. But this assumes that the "sons" schooled in statistics and agronomy had transcended their "fathers" Populist "intelligentsia legacy" of an additional allotment. Rural professionals well knew that there were instances where land shortage-either of plowland or other land resources needed for a complete household economy-required redress before improved/intensive cultivation could make an actual difference in productivity and livelihood. GZK members and other experts in the League of Agrarian Reforms recognized this principle-the fact that land reform and agrarian improvement were essential parts of the same process of "solving" the agrarian question. Furthermore, having to conform professional worldviews to changing political realities is not uncommon and is typical for most experts then and now. The majority of urban experts, despite disappointments and frustrations, applied their expertise to the problem at hand: devising a means for redistributing the national land fund in an equitable (i.e., just) manner. Revolution did not yield agrarian experts the agrarian reform they had worked for pre-1914, but rather put them in the position to apply their expertise, at least on paper, to correcting the ills of 1861 in their current context. In doing so, they hoped to create a mechanism that well positioned rural Russia to realize their professional aims in the future-a vibrant and productive national peasant economy.

9 The main task of considering the basis for allotting the national land reserve fell to a commission chaired by the Socialist Revolutionary party's S.L. Maslov. Charged with drafting a plan for redistributing land, the commission heard reports by agrarian 
economists N.P. Makarov, B.V. Volkov and B.D. Brutskus, and debated them at three meetings in July and August $1917 .{ }^{27}$ Unlike previous reformers, the assembled experts were not constrained by the need to preserve noble landholding, but rather by deteriorating circumstances in the countryside and the knowledge that available land resources would not allow them to allot land with any sort of arithmetic equality. Makarov's report became the main basis for the commission's resolutions passed and submitted to the GZK on August 24. He argued that the norms of 1861 would be inappropriate in 1917, even though they recognized key geographic variations, as by 1917 it was clear that not enough arable land existed to apply them. ${ }^{28} \mathrm{He}$ then outlined the bases, strengths and weaknesses of allotting land by a consumption (potrebitel'naia) or labor (trudovaia) norm. Allotting land according to a consumption norm (ensuring households access to the plowland needed to meet their consumption needs, based on average yields and market prices, of an average household in the area) would result in some households holding more land that they could work and encourage households to continuously expand their needs. Conversely, allotting land according to a labor norm (ensuring households access to the plowland required to occupy its entire labor force during peak agricultural periods without recourse to hired labor) introduced a number of additional variables such as the intensification of the household's economic organization and variations in the agricultural calendar. Given regional variations and that there was not enough land to allot households a full amount according to either of these norms, Makarov called for deriving and applying a combined consumption-labor norm (an average based on land held by groups of households in each region that met their consumption needs sufficiently and employed their full labor force without recourse to hired labor), that would include consideration of a norm for non-agricultural income ( promysly). He proposed that the state resolve any remaining inequalities in land distribution through migration and the tax system. Lack of resources, in his mind, also meant that only households currently engaged in farming should receive land (as opposed to more radical calls that all wanting land should receive an allotment). ${ }^{29}$

B.V. Volkov's report agreed with Makarov's conclusions, although he argued the case for the more radical SR position of a universal right to land and the elimination of peasant need to secure non-agricultural income..$^{30}$ The report by economist Boris D. Brutskus spoke against Makarov's proposals, arguing that undertaking the massive project of calculating and applying norms was too complicated and divorced from current rural realities. Peasants were thinking only in local terms and would not tolerate the resettlement of outsiders included in Makarov's plan. Nor would they tolerate any reduction in the land they currently held on the basis of non-agricultural income, even if the Constituent Assembly established and sanctioned such norms. Brutskus urged a more realistic assessment of the peasant perspective. The simplest thing to do (and what was essentially happening) given the fact that peasants already farmed the majority of available land was to simply give the land to those tilling it. Brutskus lamented the fact that allotting peasants land under current circumstances would reduce grain production and reverse recent agronomic gains by encouraging extensive cultivation. ${ }^{31}$

In the discussion of the reports, only Brutskus and A.Ia. Piletskii, spoke out against norms flatly. Most found something with which to quibble in Makarov's report, but accepted norms as the best and most rational means of carrying out the task of land redistribution. The chair, S.L. Maslov criticized Brutskus for offering little beyond the failed allotment process of 1861 (i.e., for going with what was expedient rather than determining norms 
scientifically). A.A. Kaufman-with experience in land settlement in Siberia from both an academic and ministerial perspective-attempted to synthesize the two positions, calling for norms derived from "real life" that could be verified eventually. ${ }^{32}$ The agrarian economist A.N. Chelintsev, who hinted at agreement with Brutskus, mainly objected to provisions whereby use of hired labor became an indicator that land holding exceeded household labor capacity. He also thought Brutskus gave peasants too little credit for being able to engage in improved tillage after an allotment process. ${ }^{33}$ Most disagreements focused not on the use of norms (or even how they should be calculated), but rather on the questions of who should establish them (national vs. local institutions), to what territorial unit they should be applied, the extent to which non-agricultural income should be factored into the equation, and whether migration might be used to facilitate land equalization. ${ }^{34}$ Those disagreeing with the idea of norms, did not object to their usefulness in their entirety or think them unjust. Even through Brutskus saw them as futile, he admitted their usefulness for distributing lands not already under peasant cultivation. The main objection to the use of norms was actually an accurate assessment of current events. As N.P. Oganovskii noted, norms were expected by many, but might not be in tune with political reality or the peasant demands. Better to simply let peasants till what they were tilling, allot that small portion outside of this by some sort of norm, and then get on to the business of encouraging intensification. ${ }^{35}$

Despite these concerns the commission approved and submitted to the GZK final resolutions that called for allocating the national land reserve according to land norms "based on the land utilization of the average local consumer-labor holding as determined (based on local conditions) by an adequate satisfaction of needs, the utilization of a family's labor force for agricultural work, and the absence of regularly hired agricultural workers." In addition, in areas where non-agricultural income played an important economic role, "the effect of these earnings should be taken into consideration in the land allotment process, except in those cases where the scarcity of land fails to provide sufficiently high and stable incomes without such employment." ${ }^{\prime 6}$ The Commission was content with the idea that the amount of land allotted to the toiler should never fall below the subsistence level nor exceed the level beyond which the household required hired labor. This precedent for the future amounted to the same guarantee of sufficiency of the Emancipation legislation and reform proposals from the Stolypin period such as access to Peasant Land Bank credit-enough land to keep peasant households in the "middle."

\section{The peasantry and land norms}

Peasants were accustomed to looking to the state for a solution to their land needs since at least the Emancipation, and recent studies have tied their turn to violence in 1905-1907 (which became a precedent for the seizure of estates in 1917) with state failure, particularly the promise of the Duma to meet their needs. ${ }^{37}$ Petitions for an additional allotment of plowland or other type of arable persisted throughout 1917. That the Ministry of Agriculture chose to delay decision on all but a few of these petitions pending comprehensive land reform by the Constituent Assembly provided additional frustration for peasants acculturated to making use of official processes, and contributed to their transformation from petitioners to activists. ${ }^{38}$ Mobilized by the war and the legacy of 1905 , peasants soon grasped their emerging autonomy in a new world where the state's 
inability to respond to petitions existed side-by-side with an inability to coerce. ${ }^{39}$ Peasant congresses viewed land reform as an intentional state reversal of the cut-offs (otrezki) of 1861 , an act of social justice that removed from owners "the part of land not worked by the owner's own labor." ${ }^{40}$ Of course, determining peasant voice can be difficult, but based on the resolutions of local peasant congresses and volost land committees, peasants shared the GZK's conceptualization of allotment norms as a mechanism of reform, expression of social justice, and corrective to the "insufficient allotments" of 1861, even if they differed on the question of whether or not the reform should aim primarily at local rather than national needs, and even if they shaped allotment norms to correspond with their local sense of need and lore. ${ }^{41}$

Local land committees based their actions on two sources of information, reflecting the bifurcation of authority after February. They submitted numerous requests for GZK publications, particularly pamphlets on land distribution. More than 120 pages of correspondence with local land committees and other institutions in GZK records are requests for its publications related to the establishment of local land committees and land norms, particularly reports on the latter by Makarov, Kaufman and Chelintsev. ${ }^{42}$ Resolutions on the land question by national and local peasant congresses and soviets provided local committees a second source of information. Peasant congresses, although populated by peasant deputies, tended to be driven by political activists seeking to woo peasant constituents and establish their land reform credentials..$^{43}$ In the absence of clear direction, even local Provisional Government officials took their cues from these resolutions and became dismayed as the bifurcation of the dominant SR party disrupted the semblance of stability provided by the First All-Russian Peasant Congress' resolutions. ${ }^{44}$ The main thrust of the peasant congress resolutions, encapsulated in the First Congress' May 1917 "Model Mandate" (based on a synthesis of 242 local mandates presented by deputies) called for the abolition of private property in land, its recognition as national property (consistent with past state hesitancy to privatize anything considered necessary for supporting the commonweal ${ }^{45}$ ), and the alienation of all land and inventory in private and state hands for distribution to, and use by, all desiring to work it with their own family labor (with the question of redemption to be decided by the Constituent Assembly). The distribution of alienated land among the laboring population was to take place on the basis of equality and in accordance with local conditions on the basis of a labor or consumption norm, with periodic repartitions connected to the growth of the population under the guidance of both central and local institutions of self-governance, including the commune. ${ }^{46}$

15 Provincial peasant congress resolutions informed national ones, which transmitted them back to the provinces in an amalgamated form. The provincial land committees drew inspiration from both. There was often personnel overlap between the congresses and land committees. The chair of the Mogilev Provincial Land Committee was an active participant in the province's peasant con-gresses. ${ }^{47}$ Provincial and district (uezd) land committees populated by (in addition to Provisional Government officials) zemstvo professionals and more advanced peasant activists diligently sought to both carry out the GZK's information requests and regulate land use in a manner conducive to grain production. The Samara provincial land committee illustrates this well. On one hand, the provincial land committee took as a guide for managing land relations the "Temporary Rules of Land Use in Samara Province Prior to the Constituent Assembly" passed by the Second Samara Province Peasant Congress, agreeing in its mid-July meeting to publish 
and distribute copies of the rules and draft resolutions about their implementation. At the same time, the committee passed resolutions aimed at fulfilling the GZK's requests. ${ }^{48}$

To the extent that the Samara provincial land committee's actions were perhaps atypical, the difference stemmed from the fact that it had an exceptionally competent agricultural statistician in place who, having studied the question of land norms for over ten years, presented a detailed report on land norms for the committee's consideration. Grigorii I. Baskin, working from the premises of economist S.N. Iuzhakov, reached a similar conclusion as the GZK : that neither a labor norm nor a consumption norm on their own adequately accounted for all peasant households' ability to use their available labor supply to meet their needs-that neither on its own could equitably achieve a desired increase in households' well-being. ${ }^{49}$ Baskin suggested that while typical indicators such as the number of adult male workers and draft animals were important, the transition of many peasant households from a "natural economy" to a monetized one meant that any analysis aimed at determining norms reflective of both labor and consumption needed to consider distance to markets (and hence, actual market participation) as a key analytical indicator. Baskin's report also raised the issue of non-agricultural employment and the role that such income should play in determining the allotment norm for each locale. ${ }^{50}$ Accepting his analysis, the provincial committee required district and volost committees to obtain answers to questions in addition to those posed by the GZK for the derivation and application of a norm-based land reform. The questions were a public opinion survey of key difficulties associated with land reform that Baskin's report raised in the minds of the provincial committee representatives, particularly questions aimed at determining who should get land (Adult males only? Absentees on otkhod? Newcomers? Settled wage laborers?), whether or not those with non-agricultural income should be allotted land, attitudes on the commune and communal reorganization, attitudes toward Stolypin separators, and opinion on the size of consumption and labor land allotments. ${ }^{51}$

Unfortunately, we do not have the responses to these questions from Samara's uezd and volost land committees. We do, however, have the resolutions of volost and district land committees from other provinces, which reveal the extent to which peasants expected and defined allotment by norm. In Vologda province, the Golovetsk volost land committee, meeting at the end of June, called for the transfer of all land to the laboring peasantry and for continued state developmental assistance for the volost's agricultural economy, including supplying households with the implements needed for farming and forestry. The volost committee also called on the state to use its authority to transfer forests suitable for clearing as hayfields in neighboring Razgortsk volost to Golovetsk volost, as Razgortsk, in its assessment, already had adequate hayfields and as the desired forests were located too far from Razgortsk to do inhabitants any good..$^{52}$ The Semeikovsk volost land committee also requested agronomic assistance in its resolutions, called for each peasant to have at least six desiatiny of land in one spot and, given that the district's poor soil quality required "more agronomic cultivation" asked the state to provide agricultural implements at a reduced price.$^{53}$ In essence, committee resolutions asked the state to continue its project of re-ordering the countryside, a project with which it had been engaged in various forms over the previous century.

In addition to expectations of state assistance in creating a new agrarian order, the volost committees also turned to allotment norms as the proper means for allotting land, expressing them sometimes as labor norms and sometimes with no stated rationale at all. Thus Vologda's Veprevsk volost land committee resolved that 
[...] all land belongs to the laboring peasantry as a whole according to a norm of cultivation from the general state land fond no greater than $7 \frac{1}{2}$ des. per good, strong worker able to cultivate the following : $3 \frac{1}{2}$ desiatiny of arable land, based on 28 working days in a month, $1 / 2$ desiatina sown in winter crops, $1 / 2$ desiatina in spring crops and $1 / 2$ desiatina of fallow ; besides this it is necessary to have a reserve of $1 / 2$ desiatina per person and $1 \frac{1}{2}$ desiatiny of pastureland. This is all based on extended experience from a purely practical point of view. In addition, all require access for purposes of heating and building repairs to a necessary amount of either communal or state forest reserves. ${ }^{54}$

19 Vologda's Sychevsk volost land committee issued similar resolutions, calling for land from the state land fund to be allotted according to a "norm of cultivation (po norme obrabotki)." ${ }^{55}$ In Poltava the Mashevsk volost land committee, inundated by returning soldiers, resolved on 23 July to temporarily prioritize soldiers in the allotment process (whether out of a sense of patriotism or fear is not known) by establishing a "norm of [land] rental per household" of up to six desiatiny depending on its ability to work the land with its own labor. In Riazan' the Andreevsk volost land committee, reflecting debate by all the volost's communal assemblies, resolved that the "labor norm for the alienation of land" should be applied equally to all farmers, including nobles opting to participate under these terms. ${ }^{56}$ In other words, even prior to the Bolsheviks' Decree on Land peasants were already incorporating the language of norms to division of the available land fund, not as part of a national plan, but simply as a means of absorbing what land existed.

\section{Land norms and the red repartition}

The Bolsheviks inherited the "land norm" idea (and the professional staff of the GZK and Agriculture Ministry), although for Lenin and his colleagues, land norms corresponded more to the needs of the moment than their vision an agrarian future based on large-scale farming operations. ${ }^{57} \mathrm{~A}$ decade earlier, Lenin viewed the "norm" idea as evidence of a Kadet desire to preserve a pomeshchik economy behind a veil of reform and Populist timidity. ${ }^{58}$ October changed all of this, as the new regime nationalized all lands and now required a means to distribute them. Despite their own plans and suspicion of peasants, the Bolsheviks had to make land norms their own, especially given their alliance with the Left SRs, their reliance on existing professionals, and the reality of events in the countryside. The Congress of Soviets of Workers and Soldiers Deputies Decree on Land of 26 October 1917 specified land reform terms that, other than blatantly abolishing private property in land, bore a striking resemblance to pre-October proposals. "Highly cultured" estates such as gardens, nurseries, and orchards were to be kept intact as state property, as were pedigreed livestock herds. Those capable of working land received equal use rights based on local land use conditions and either labor or consumption norms. State-sponsored migration by volunteers or discredited commune members (e.g., deserters) would eventually alleviate land shortages in the densest regions..$^{59}$ By December there were decrees creating the machinery for land distribution : a main land committee supervising local committees charged with inventorying and distributing local resources to qualified recipients. ${ }^{60}$ The state served as the primary agent for transforming a national economy and, through the local soviets, overseer of the process of meting out social justice. 
This was to be a grand reconciliation of the sins of 1861, symbolized by issuance of the Basic Law on the Socialization of Land on the Emancipation's anniversary (February 19, 1918). The statute aimed to control spontaneous land seizures to ensure that land redistributions corresponded with state and peasant needs, and reflected experts' realization that events had increased the complexities of implementation. Despite central attempts to gather information and manage the process, including sending surveyors and other professionals to the village, the actions of local communes prevailed. ${ }^{61}$ As the food situation deteriorated and the influx of urbanites and demobilizing soldiers flooded villages, achieving equal land distributions that respected the labor principle and improved households' wellbeing made balancing both labor and consumption norms more difficult and more important. Defining what unit to use for determining norms was challenging. "Revisional souls" were now obsolete, relegated to history's dustbin by the revolution. Balancing allotment by "eaters" with the labor norm idea that land belonged to those who worked it themselves remained administrators' chief difficulty, as emphasis on the "laboring peasantry" or the "labor economy" encapsulated in the "labor norm" idea conflicted even more with a hungry population's need for allotment norms based on consumption. Labor norms also proved problematic because they tended to favor large families perceived as being class enemies (kulaks). In practice, the right to eat outweighed the labor norm and the application of some sort of a consumption norm, in some ways the most radical alternative, prevailed..$^{62}$ In the aggregate, the amount of land gained by any one household was negligible with the exception of steppe provinces. At the same time (and despite jockeying within the village by households seeking to maximize their additional land eligibility), over the course of 1918-1920 landless and land hungry peasants eventually were able to improve their positions. As Atkinson put it (referring to the process of state formation under Ivan III), the Bolshevik state's "regathering of the lands" had resulted in a substantial leveling of rural society." ${ }^{63}$ In this sense, allotment according to norm had served the interests of social justice in that it addressed the chief complaints of peasants and their advocates.

Bolshevik policy increasingly aimed toward an Aristotelian mean in land relations, despite rhetoric privileging poor households over others. "The distribution of land between laborers," Article 12 stated,

must be carried out on equalizing-labor bases such that the consumption-labor norm pertaining in a given region to the historically formed system of land use does not exceed the labor capacity (trudosposobnosti) [...] of each individual household and, at the same time, would provide the possibility of a comfortable ( bezbednogo) existence to the farmer's family. ${ }^{64}$

23 Aiming towards the middle, the instructions for determining norms specified guidelines for determining average production figures for all types of arable in a given region and average peasant landholding (including use of purchased and rented lands prior to 1917). ${ }^{65}$ They also marked a milestone in rural studies, as experts finally agreed which household members should be counted as unable to work, and what portion of a worker women and older children would count as in labor norm calculations. ${ }^{66}$ The instructions granted exceptions allowing allotments of land beyond the norm for households overburdened by non-workers, holding poor quality existing allotments, or receiving poor quality additional allotments. universalizing ideology. This reflected the input of experts anxious to ensure that 
redistributions justly reflected variations in soil quality and other factors at the local level. Perhaps they also realized that volost committees were already in charge. In a few places, uezd officials created special organizations to establish norms-with or without the assistance of local experts. For example, Stavropol' uezd (Stavropol') established a special commission of representatives for this work, while Petrograd province invited communal representatives to serve as permanent members of the land department for determining the allotment norm. As we might expect, the local implementation of specialists' meticulously crafted guidelines often fell apart due to the complexity of trying to adapt norms established for the "average" or "typical" family to different combinations of workers and "eaters" in individual households. According to one study, 108 of 132 uezdy simply used "eater" as the primary unit of land distribution. Use of the labor norm tended to prevail in the areas bordering European Russia. The central provinces claimed to divide land by "eater," but often just followed the provisional land division made prior to calculating and assigning norms, which local officials viewed as in the interests of the poor. Local perceptions of who was in need often drove the process. In several cases, local peasants resisted application of labor norms over consumption norms, believing that labor norms favored kulak households. As such, consumption norms alone often prevailed ${ }^{67}$ At the same time, evidence indicates that when peasant communities imposed their own divisions, they sought out state bodies to provide their decisions with legitimacy. ${ }^{68}$

of the local particularisms experts considered, soil variations in provinces and uezdy were the most important. This complicated the allotment process, leading to the establishment of separate allotment norms for different soil categories. Prior to 1917, the use of soil data caused a certain amount of turmoil in zemstvo circles. Even though zemstvo statisticians factored soil quality into assessments, they resisted the idea that this factor always outweighed social factors in computing land values. ${ }^{69}$ Now that all land belonged to peasants, however, arguments about the particularisms of peasant husbandry were moot and soil quality became a primary factor in equitable distributions. Although some areas, such as Nizhnii-Novgorod province attempted to make use of existing soil data, many local committees simply divided land into "black soil," "transitional," and "non-black soil" or "good," "average," and "poor" sectors, placing volost land into each category based on ten-year harvest averages. Most instructions simply mentioned considering soil quality in calculations without specifying how, which in most cases simply resulted in considering soil quality along the same lines as communes did in their repartitions. ${ }^{70}$

At the end of the day, the most important factor affecting allotment norm size after October (as peasants already realized over the summer of 1917) was simply the amount of land available for redistribution. Often, boards merely divided the amount of available land by the number of people or "eaters" employed in farming, making the norm essentially an arithmetic factor of the quantity of land and the density of the population. Norms established in many local statutes were reduced owing to a lack of available land, or at least available land near enough to needy households as to be useful. In these cases land was often allotted much like it was in the Emancipation-according to existing average allotment size. In some cases, officials remained in the same difficult position as their imperial predecessors in that population density rendered an equal redistribution on any basis nonsensical, as it would result in depriving all households of a sufficient allotment. ${ }^{71}$ Even if applying norms in the field proved difficult or impractical, however, the norms and instructions reflected the aims of the experts who devised them. The 
concepts of "sufficiency," and the labor household prevailed and pointed not just to an equitable distribution of the new national land fund, but a distribution designed to bolster the land-short at the expense of those who, by the rules, had too much. As the chronicler of these events, GZK member P.N. Pershin noted, "norms of land use played a necessary role [in land redistribution] to the extent that they conveyed the interests of the poor and middle peasantry, supplying it with favorable conditions for the conduct of an economy and, along with the prohibition on hired labor, depriving the kulak strata of the village of agro-economic primacy." ${ }^{\text {"2 }}$ For the Soviet state land allotment norms represented the rational implementation of a class-based system of social justice, although one frequently supplanted by material realities, local officials, and the peasants themselves.

\section{Land norms and the whites}

That White governments turned to land norms and a commitment to laboring households (at least on paper) testifies to the deep penetration of the idea of norms into all levels of imperial society, a penetration facilitated by the fact that the White movement inherited its share of agrarian experts and technocrats from the old regime. ${ }^{73}$ White reform proposals all endorsed a transfer of land allotments imbued with property rights to the laboring peasantry according to some concept of allotment norms. Estate owners could find in norms a guarantee that they would at least retain some of their land-more if they could prove that theirs was an intensively farmed property or one employing a special form of husbandry. White leaders hoped that peasants would interpret their norms and property guarantees as a better alternative to Bolshevik decrees. By 1918, however, compensation was a non-starter for most peasants, especially as Bolshevik land policies legitimated land seizures up to a given norm without requiring compensation to former owners. Norms were a convenient tool for White leaders when it came to walking the fine line between their noble officers and the peasants who fed them, but the White leadership's inability to move beyond the idea of compensation doomed their reforms and any chance of peasant support to defeat.

In Siberia, 1919 decrees by Admiral A.V. Kolchak guaranteed sowers a right to harvest the lands they planted, even if such lands were subsequently returned to owners, and offered the possibility of acquiring full property rights over sown lands for laboring peasant households. ${ }^{74}$ Kolchak (like other White commanders) apparently favored a program of "khutorization." The land decrees' emphases on "working peasant households" reflected belief that there should be a connection between land allotments and ability to work them without hired labor. In the Don Territory, Cossack resentment over the state's award of land to Cossack bureaucrats in lieu of salary and hostility toward land speculators led to near unanimous support for seizing private lands for redistribution when the Krug for the Salvation of the Don met in July and August $1918 .^{75}$ The resultant land reform law set norms for private property at 30 to 50 desiatiny, with land above this norm to be alienated and allotted to land short Cossacks and native peasants free of charge. Owners would be compensated for buildings and improvements, but not the land itself. As with other White land reform programs, the need for grain and revenue distorted policy implementation. In the Don, free distribution turned into leasing in kind, and some parcels actually went up for auction, undermining the authorities' credibility. ${ }^{76}$ 
The Volunteer Army's land policies illustrate the White predicament and the use of land norms in the South. With a constitution focused on private property and the rule of law and a governing council that never discussed land reform, it would seem that peasants had little chance of acquiring additional land. ${ }^{77}$ The influence of former landowners and those opposed to expropriation of any sort was strong among White leaders' inner circles. At the same time, there is evidence that this should be interpreted less as an inherent antipathy to land reform and more as simply a statement of what the Constitution's Kadet authors valued most : the rule of law and the primacy of the Constituent Assembly in addressing reform issues. ${ }^{78}$ The essence of the White proposals, in the South and elsewhere, aimed at a "consolidation of the average [household] economy" as the basis for a stable and productive countryside-a wager on the middle peasant who would have enough to maintain a stable economic life but not enough to potentially exploit neighbors. ${ }^{79}$ General Anton I. Denikin's attempts to gain peasant support through land reform aimed to fulfill the aspirations of landowners, peasants and procurement officers alike, a balancing act bequeathed to his successors. Land norms provided a mechanism that met this need. Denikin's attempts to secure support for a land reform came to naught, but embodied the key ideas ultimately incorporated into his successor's decrees. According to Denikin, land reform should safeguard the interests of the working population by strengthening small- and medium-sized holdings at the expense of the state and large landowners while preserving owners' property rights. District committees should determine the size of maximum holdings and subject lands in excess of the maximum to compensated forcible alienation. Highly productive estates, forests, land unsuitable for cultivation, and Cossack lands remained inviolable. All landowners should receive state aid to stimulate production. In essence, Denikin was prepared to allot land according to availability and norms under some system of compensation to landowners. ${ }^{80}$

By 1920 defeats and the reality of peasant land seizures forced even opponents of land reform outside of a Constituent Assembly, including General P.N. Wrangel and former Minister of Agriculture A.V. Krivoshein, to admit that the land question required action. Wrangel appointed a committee under Senator G.V. Glinka to devise a reform project. ${ }^{81}$ Glinka was well suited to oversee the project given his ministerial experience in implementing the Stolypin reforms..$^{82}$ On the $20^{\text {th }}$ of April Wrangel sent a memorandum to the committee outlining his expectations that bore much resemblance to Denikin's earlier proposal. It affirmed his commitment to private property, and demanded that land "should belong to those who work it" and not "be subject to renting or speculation." Furthermore, "Depending on the availability of land, on density of population, and on the prevailing type of agriculture, norms should be established in such a way as to suit different circumstances (in districts and in provinces)" with lands beyond these norms subject to alienation (with the exception of intensely cultivated estates and special farms. Those receiving land would be responsible for compensating its former owners. ${ }^{83}$ The committee's initial work disappointed Wrangel, but a subsequent revision became the basis for two orders in 1920 that largely followed his original instructions, but contained stronger language related to compensation and defined how local committees would determine land values. ${ }^{84}$

31 Wrangel's land policy, according to Senator Glinka and as manifest in the 1920 Order on Land (Prikaz o zemle), proceeded from the right of private property in land "as the singular foundational basis of a proper state land structure" and was the primary distinguishing feature between Wrangel's policy and that of the Soviets. Referencing Peter the Great, 
however, Glinka noted that this foundational principle was subject to modification by the state, which served as the final arbiter of land tenure and which possessed the power of eminent domain to advance its interests..$^{85}$ At the same time, Wrangel also acknowledged the right of all current farmers "to a defined quantity of land" (as established by the Emancipation). The state's role, and the aim of the Order, was balancing these two ideas to benefit the common good. Alienation with compensation was a traditional principle of the legal system since 1861. The benefits of free labor applied to property inherent in the Emancipation strengthened the principle of property ownership in the Order on Land. If this was socialism, Glinka argued-taking a swipe at critics from the right-then it was socialism from the throne. The project's aim at breaking up large estates was not introducing a new idea into the countryside, but merely continuing the process begun by the Emancipation (and also well in line with conceptions of property as a public good). Glinka contrasted this approach, rooted in the Emancipation's land allotment and redemption process for existing local farmers and that of the socialists' promises of land to anyone on the basis of some future land order. Wrangel, Glinka argued, was offering something real. ${ }^{86}$ Thus, a type of eminent domain rooted in Russia's past and the expansion of private property ownership oddly went hand-in-hand in Wrangel's Order. This is also apparent in its redemption process where, in contrast to the Emancipation's redemption operation, the real benefit of the redemption process under the Order's implementation terms went not to those being compensated, but rather to the peasant payers themselves. This was the key to reinforcing the value of property ownership. The actual sufficiency of the payment for the owner experiencing compulsory alienation was not the main guide in determining the size of payments. Furthermore, although the state would certainly accept cash and a shortened redemption time line if offered, the payment structure reflected a moral economy approach : one-fifth of the average harvest yielded by the land being redeemed over twenty-five years, thus making both the state and the new property owners equal partners in the assumption of agrarian risk. ${ }^{87}$

Besides a commitment to spreading property ownership and compensating former owners, the Order differed from the GZK and Bolshevik approaches in two other ways. First, Wrangel believed that any allotment of land was a local affair for local persons. There was no single solution to the land question on an all-Russian scale, and as such, the details of land reform in each locale were best left to local institutions such as the volost ("peasant") and district zemstvos. ${ }^{88}$ This represented a more decentralized approach to the land question than that of the GZK and Bolsheviks. Second, although the issue of allotting land to anyone who desired it divided the GZK membership, in the end the SR belief in allotting land to all who desired it and could till it with their own hands prevailed and made it in to the Bolshevik land decrees. Wrangel adamantly opposed this, not only on the basis of practicality and rural stability, but also based on the deeply rooted value of a connection to land and place. Only farmers already in situ and engaged in farming there should receive land. The "socialist" plan to relocate peasants from one place to another was "incompatible with the basic freedom to establish an economic life that belongs to everyone." ${ }^{89}$ According to Glinka, this distinguished Wrangel's project from that of the Soviets.

Second, the Order took great care to distinguish itself from the Bolsheviks and other socialists in its use of land norms. The GZK and Bolshevik projects' use of norms aimed at assuring peasants a subsistence niche : labor and consumption norms aimed to provide households the minimum land allotment required to apply the household's labor/meet its 
consumption needs. They were norms based on the idea of correcting "insufficient" allotments by making them "sufficient." Wrangel's Order, with its emphasis on the local allotment of land to local farmers assured them "not an amount of land calculated according to some sort of utopian provisioning or consumption norm that one might desire, but only that [amount of land] which one has the ability to manage, that is to cultivate." Rather than "sufficiency," the Order's conception of norms stemmed from an idea of maximum allotments rooted in past tsarist discussions of agrarian reform, harkening back to the Stolypin Reforms' prelude and V.I.Gurko's proposed use of maximums to break up the empire's large latifundia in order to increase peasant land allotments. ${ }^{91}$ The Emancipation statute set maximum allotment norms, as did other tsarist initiatives such as the maximum amount of land any one household was allowed to accumulate according to the rules governing the Peasant Land Bank. The Bank established these regional norms in the $1890 \mathrm{~s}^{92}$ In reality, these Peasant Land Bank maximums, stipulated by the Order on Land, were labor norms-the maximum amount of land for a given region that an average family could work with its own labor. As Glinka noted,

It may be bad or good, but all land management practices proceed from the fact and only from the fact of farming itself, and from the practical size of land use, which should not leave land un-worked and should not be outside the closest connection to the landholder himself. ${ }^{93}$

Although Glinka and the Order assiduously sought to avoid using the same language of norms found in the work of the GZK and the Bolshevik land decrees, at the end of the day the transfer of land to the laboring population (here more broadly defined in class terms) according to a household's ability to live on it and work it was, for all intents and purposes a White labor norm.

We generally pass over Wrangel's Order on Land as a curiosity-another case of White leaders doing too little, too late. Naturally, it differed in key ways from the GZK projects and Bolshevik land decrees, which envisioned implementation of single national plans of reform (albeit via mechanisms that provided for local input and implementation). The Wrangel Order placed more emphasis on the local than the GZK intended for local land committees. Wrangel's volost ("peasant") zemstvo was assigned a roll in the land reform process that the GZK's local land committees had essentially seized (much to many GZK members' dismay), and which the Bolsheviks then legitimated and directed into local soviets. Furthermore, in line with its emphasis on the local, the Wrangel Order limited land allotment to local inhabitants already farming in the area. This was a departure from GZK and Bolshevik plans to eventually move people from land poor to land rich regions as well as a departure from the plans of more radical GZK members and Bolsheviks to allot land to all who wanted to farm it with their own labor. The most profound difference, of course, was the White insistence on allotting land as private property (as opposed to allotting land for use only) and the redemption program (despite its claims to be weighted in favor of those redeeming it rather than former owners). Even though the proposed redemption operation bore a striking resemblance to the future NEP tax-in-kind and even though there were peasant communities willing to pay a "fair price" for the land, by the summer of 1917 redemption on any basis was a dead issue. Finally, Wrangel's Order connected itself to the Emancipation, proceeding from the premise of land ownership maximums based on existing institutional norms rather than the premise of correcting the ills of 1861 by satisfying the quest for "sufficient allotments." 


\section{Conclusion}

36 the programs of the GZK, the Bolsheviks, and the peasants themselves. Rather than being yet another example of the Provisional Government's failure, the work of the GZK, succeeded in establishing and perpetuating the language and framework-the allotment norm-that defined the terms and process of land reform (at least on paper) and the pursuit of social justice for a diverse array of socio-political actors. All parties viewed land reform as a state obligation to allot land. In one way or another, all saw this as a moral obligation to correctly implement the land allotment promise of 1861 to the laboring peasantry. For all participants, land norms provided a measureable means to equitably implement social justice. Although divided on a host of other social and political issues, the place of land norms as the best available mechanism for ensuring the state's just distribution of available land provided a common interpretive framework for all parties in 1917, a framework reflective of the agrarian consensus that had developed in the preceding decade and of the technocratic statist perspective of the experts propelled into the position of policy makers by war and revolution. In addition to their apparent objectivity and fairness, norms represented for experts a guarantee that the state's distribution of the land fond would have some chance of advancing their pre-war agenda for agricultural development. Managed extensification by norm could not only ensure a just land distribution, but also pave the way for continuing the work of land reorganization and technical improvement initiated over the preceding decade by the state, the zemstvos, and agrarian professionals and for fulfilling the state's moral obligations.

In one sense, the revolution opened new doors for agrarian professionals, policy makers and the objects of their work-peasants-by deciding once and for all that Russia's agrarian future, at least for the time being, was to rest on the household economies of peasant small-holders provided with normatized land allotments and agronomic assistance. The key to Russia's agrarian future-whether Imperial, Soviet, or something in between-was neither a two-tiered economy (peasant and pomeshchik), nor a Stolypin-esque "wager on the strong," but rather a wager on a rural economy where farmers had sufficient access to land as a first step toward increasing productivity through improved husbandry. Peasant household economies damaged by the "cut-offs" of 1861 could now be healed, and all farmers, by a combination of means, given the subsistence means required to become legitimate actors in the new national economy. In essence, this was a revolutionary attempt to normatize the social structure of the countryside as a whole by means of privileging a nostalgic connection between the farmer and the soil that could only be found among households with enough land to meet their consumption needs and occupy their complete labor force, but no more. The main beneficiary of this vision of the agrarian future was the middle peasant-the seredniak. For the experts of the GZK and League of Agrarian Reforms such as Professor A.A. Rybnikov, the experience of Western Europe had already demonstrated the efficacy of mid-sized farms as engines of rural economic development. ${ }^{94}$ By 1919, Lenin argued to the Eighth Party Congress that the seredniak had become a potential ally in guaranteeing the Revolution's survival and feeding the population. ${ }^{95}$ By 1920, farms of middling size based on land allotment maximums provided the retreating whites with some guarantee that 
former noble landowners might have some place in the new agrarian order. In this way, land norms pointed toward a just solution to the land question that would create a unified agrarian economy poised for development, allowing the state to fulfill the 1861 Emancipation's moral promise.

Yet, in the end, differing conceptions of this moral commitment-the specifics of local conditions and politics-overrode the theoretical objectivity of norms, especially as the need to feed came to dominate state and local agendas and peasant impatience combined with a sense of agency to advance parochial interests at the expense of national ones. Thus, for the Bolsheviks, land allotment norms were useful only in as much as they provided a convenient mechanism for ensuring a just division of the spoils that would advantage potential village allies to the detriment of class foes and facilitate grain production. For the Whites, land norms perpetuated a statist approach to agrarian reform that provided political cover from the right and left for leaders who belatedly realized land reform's political necessity. Peasants accepted the concept of allotment by norm, adapting it to fit their local needs and ideas of what constituted "sufficient," but did so with little regard to how local land resources might fit into a national program of land reform. In their application, norms as tied to local notions of "sufficiency" and local assessments of resources could prevent neither economic chaos nor a violent realization of the "black repartition" (chernyi peredel) long dreaded by some and desired by others.

\section{NOTES}

1. On earlier efforts to apply normatized land allotments, see Glavnoe upravlenie udelov, Istoriia udelov za stoletie ikh sushchestvovaniia, 1797-1897 [The history of the appanages for A hundred years of their existence, 1797-1897], 3 vols. (SPb.: Tip. Glavnago upravleniia udelov, 1901); N.M. Druzhinin, Gosudarstvennye krest'iane i reforma P.D. Kiseleva [The state peasantry and the reforms of P.D. Kiselev], 2 vols. (M. : AN SSSR, 1946 and 1958); Willard Sunderland, Taming the Wild Field: Colonization and Empire on the Russian Steppe (Ithaca : Cornell University Press, 2004) ; David W. Darrow, "Statistics and Sufficiency: Toward an Intellectual History of Russia's Rural Crisis," Continuity and Change 17, 1 (2002) : 63-96 ; I.A. Khristoforov, "Ot Speranskogo do Stolypina: Krest'ianskaia reforma i problema zemleustroistva [From Speranskii to Stolypin : Peasant reform and the problem of land settlement]," Rossiiskaia istoriia, no. 4 (2011) : 27-43. On the role of the Emancipation in Alexander II's image see Richard S. Wortman, Scenarios of Power : Myth and Ceremony in Russian Monarchy, vol. 2, From Alexander II to the Abdication of Nicholas II (Princeton : Princeton University Press, 2000), 3-14, 42-43, 58.

2. On opeka see Francis W. Wcislo, Reforming Rural Russia, 1885-1914 (Princeton: Princeton University Press, 1990); Gary Hamburg, Politics of the Russian Nobility, 1881-1905 (New Brunswick, NJ : Rutgers University Press, 1984), 192-200 ; George L. Yaney, The Urge to Mobilize : Agrarian Reform in Russia, 1861-1930 (Urbana, IL : University of Illinois Press, 1982), chpt. 3 ; Yanni Kotsonis, Making Peasants Backward: Agricultural Cooperatives and the Agrarian Question in Russia, 1861-1914 (New York : St. Martin's Press, 1999).

3. On gosudarstvennost' see Marc Raeff, The Well-Ordered Police State (New Haven \& London : Yale University Press, 1983); William G. Rosenberg, Liberals in the Russian Revolution: The 
Constitutional Democratic Party, 1917-1921 (Princeton: Princeton University Press, 1974), 134-169 ; David McDonald, "1991 and the History of Russian Gosudarstvennost'," Ab imperio, 3 (2011) : 223-238. On the emergence of the idea of a "public domain" as an institutionalization of the common good see Ekaterina Pravilova, A Public Empire: Property and the Quest for the Common Good in Imperial Russia (Princeton: Princeton University Press, 2014). On fear of speculators exploitation of peasants see Kotsonis, Making Peasants Backward and Peter Holquist, "In Accord with State Interests and the People's Wishes : The Technocratic Ideology of Imperial Russia's Resettlement Administration," Slavic Review, 69, 1 (2010) : 157.

4. Kotsonis, Making Peasants Backward; Holquist, "In Accord with State Interests and the People's Wishes" ; Judith Pallot, "The Stolypin Land Reform as 'Administrative Utopia' : Images of Peasantry in Nineteenth-Century Russia," in Madhavan K.Palat, ed., Social Identities in Revolutionary Russia (New York: Palgrave Macmillan, 2001), 113-133. On peasant responses to reformers see Judith Pallot, Land Reform in Russia, 1906-1917 : Peasant Responses to Stolypin's Project of Rural Transformation (Oxford : Oxford University Press, 1999).

5. Ian W. Campbell, "Settlement Promoted, Settlement Contested: The Shcherbina Expedition of 1896-1903," Central Asian Survey, 30, 3-4 (2011) : 423-436; Holquist, "In Accord with State Interests and the People's Wishes." On emerging intellectual synergy among state officials and experts, facilitated in many ways by Finance Minister Sergei Witte's hiring practices and the Special Conference on the Needs of Agricultural see David A.J. Macey, Government and Peasant in Russia, 1861-1906 : The Prehistory of the Stolypin Reforms (DeKalb : Northern Illinois University Press, 1987).

6. On land reform proposals vetted by political parties and the Duma see Dorothy Atkinson, The End of the Russian land Commune, 1905-1930 (Stanford : Stanford University Press, 1983), chpts. 3,8 .

7. Yaney, The Urge to Mobilize. On expert adaptation in implementation see Pallot, Land Reform in Russia. On the land allotment in 1917 as a revival of the old Populist see Ilya V. Gerasimov, Modernism and Public Reform in Late Imperial Russia: Rural Professionals and Self-Organization, 1905-1930 (New York : Palgrave Macmillan, 2009), chpt. 10.

8. See A.I. Chuprov, "K voprosu ob agrarnoi reforme [On the question of agrarian reform]," in P.D. Dolgorukov, et al, eds., Agrarnyi vopros : Sbornik Statei, T. II (M. : Beseda, 1907), 1-42 ; Kimitaka Matsuzato, "Stolypinskaia reforma i rossiiskaia agrotekhnicheskaia revoliutsiia [The Stolypin reform and the Russian agrotechnical revolution]," Otechestvennaia istoriia, no. 6 (1992) : 194-200.

9. See discussions in the Special Conference on the Needs of Agriculture (Osoboe soveshchanie o nuzhdakh sel'skokhoziaistvennoi promyshlennosti) discussed in Macey, Government and Peasant in Russia, chpt. 2.

10. Although statistical studies gave the appearance that Emancipation allotments were insufficient (see Darrow, "Statistics and 'Sufficiency"), Hoch notes that peasants fared pretty well. Steven L. Hoch, "Did Russia's Emancipated Serfs Really Pay too Much for Too Little Land? Statistical Anomalies and Long Tail Distributions," Slavic Review, 63, 2 (2004) : 247-274.

11. Pallot, "The Stolypin Land Reform as “Administrative Utopia"” ; Yaney, The Urge to Mobilize, 3.

12. On agrarianism in Russia see, in addition to previously cited works by Gerasimov, Kotsonis, Holquist, and Khristoforov, Katja Bruisch, Als das Dorf noch Zukunft war: Agrarismus und Expertise, zwischen Zarenreich und Sowjetunion, Beiträge zur Geschichte Osteuropas, Band 47 (Cologne et al : Böhlau Verlag, 2014).

13. See his opening speech to the first session of the GZK, IGZK (Izvestiia Glavnago Zemel'nago Komiteta), no. 1 (15 iiulia 1917) : 5-11. Yaney has his name wrong ("D. Posnikov"-The Urge to Mobilize, 460).

14. IGZK, no. 1 (15 iiulia 1917) : 3-5. 
15. In addition to previously cited works by Kotsonis and Holquist see Alessandro Stanziani, L'économie en révolution: le cas russe, 1870-1930 (P.: A. Michel, 1998), chpt. 8 ; Naum Jasny, Soviet Economists of the Twenties : Names to Be Remembered (Cambridge : Cambridge University Press, 2008).

16. See Vremennoe Pravitel'stvo, Ministerstvo Zemledeliia, GZK, TKPZR (Trudy komissii po podgotvke zemel'noi reformy), Vyp. II, Normy zemel'nago obezpecheniia [Proceedings of the commission for the preparation of the agrarian reform. Issue II. Norms for land provision] (Pgd. : "Prosveshchenie," 1917), 36 ; TKPZR, Vyp. V, Organizatsiia territorii [Issue V, The organization of territory] (Pgd. : "Prosveshchenie," 1917), 18.

17. On the issue of peasants and property see Kotsonis, Making Peasants Backward, chpt. 2.

18. On property rights see GARF (Gosudarstvennyi Arkhiv Rossiiskoi Federatsii-State Archive of the Russian Federation), f.1796, op. 1, 1917, d.17, Materialy o deiatel'nosti komissii po zemel 'no-pravovym otnosheniiam, 3 iulia-27 noiabria $1917 \mathrm{~g}$. [Materials of the activities of the commission on land rights, 3 July-27 November 1917]; "K organizatsii rabot komissii po pravovym formam zemlevladeniia [Towards the organization of the work of the commission on the legal forms of land tenure]," IGZK, no. 4-5 (1-15 sentiabria 1917 g.) : 14-15. On other questions, see esp. TKPZR, Vyp.I, O krupnom zemlevladenii [Issue I, On large estates] (Pgd.: "Prosveshchenie," 1917) ; TKPZR, Vyp. III, O krupno-krest'ianskikh kho--ziaistvakh [Issue III, On Large Peasant Economies] (Pgd.: "Prosveshchenie," 1917); TKPZR, Vyp. IV, O kontingente khoziaistv i lits, podlezhashchikh obezpecheniiu zemlei [Issue IV, On the contingent of households and individuals subject to the provision of land] (Pgd. : "Prosveshchenie," 1917).

19. Darrow, "Statistics and Sufficiency."

20. N. Oganovskii, Agrarnyi vopros v Rossii posle $1905 \mathrm{~g}$. [The agrarian question in Russia after 1905] (Khar'kov: Tipo-Litografiia M. Sergeeva i K.Gal'chenka, 1914), 3 ; Iu.E. Ianson, Opyt statisticheskago izsledovaniia o krest'ianskikh nadelakh i platezhakh [Essay of statistical research of peasant allotments and payments], $1^{\text {st }}$ ed. (SPb. : Tip. M. Stasiulevicha, 1877).

21. Hoch demonstrated that this was not the case. See Steven L. Hoch, "The Banking Crisis, Peasant Reform, and Economic Development in Russia, 1857-1861," American Historical Review, 96 (June 1991) : 795-820.

22. N. Ozeretskovskii, “Zemel'nye komitety," IGZK, no. 1 (15 iiulia 1917 g.) : 29 ; IGZK [The land committees], nos. 2-3 (1-15 avgusta 1917 g.) : 26.

23. IGZK, no. 1 (15 iiulia 1917) : 23 ; GARF, f. 1796, op. 1, 1917, d. 24, Perepiska s Ispolnitel'nym Komitetom Vserossiiskago Soveta Krest'ianskikh Deputatov, 1.2ob [Correspondence with the executive committee of the All-Russian Soviet of peasant deputies].

24. Z.S. Katsenelenbaum, Finansovaia storona agrarnoi reformy [The financial side of agrarian reform] (M. : Universal'naia Biblioteka, 1917), 11-27 ; Hoch, “The Banking Crisis.”

25. TKPZR, Vyp. V, Organizatsiia territorii, 9-10.

26. Gerasimov, Modernism and Public Reform in Late Imperial Russia, 168.

27. TKPZR, Vyp. II, Normy zemel'nago obezpecheniia, 1.

28. A.A. Kaufman, also a member of the commission and one of the authors of the Kadet land reform program had made this apparent a decade earlier. See Kaufman, "K voprosu o normakh dopolnitel'nago nadeleniia," in Dolgorukov, et al, eds. Agrarnyi vopros : Sbornik statei, T. II, 261-304.

29. TKPZR, Vyp. II, Normy zemel'nago obezpecheniia, 2-21.

30. TKPZR, Vyp. II, Normy zemel'nago obezpecheniia, 20-21.

31. TKPZR, Vyp. II, Normy zemel'nago obezpecheniia, 27-30.

32. Kaufman had served in the Ministry of State Domains as part of a party of researchers studying peasant life and land settlement practices in Western Siberia. See his autobiography, published posthumously in Vestnik Statistiki, nos. 5-8 (1921).

33. TKPZR, Vyp. II, Normy zemel'nago obezpecheniia, 37, 39, 41. 
34. TKPZR, Vyp. II, Normy zemel'nago obezpecheniia, 40-41, 46.

35. TKPZR, Vyp. II, Normy zemel'nago obezpecheniia, 34.

36. TKPZR, Vyp. II, Normy zemel'nago obezpecheniia, 49-50.

37. Burton Richard Miller, Rural Unrest During the First Russian Revolution : Kursk Province, 1905-1906 (Budapest and New York : Central European University Press, 2013).

38. GARF f. 1797, op. 1, 1917, d. 52-55 ; Corinne Gaudin, Ruling Peasants : Village and State in Late Imperial Russia (DeKalb: Northern Illinois University Press, 2007) ; Jane Burbank, Russian Peasants Go to Court: Legal Culture in the Countryside, 1905-1917 (Bloomington: Indiana University Press, 2004).

39. Orlando Figes, Peasant Russia, Civil War : The Volga Countryside in Revolution (1917-1921) (New York : Oxford University Press, 1989) ; Aaron Retish, Russia's Peasants in Revolution and Civil War : Citizenship, Identity, and the Creation of the Soviet State, 1917-1922 (Cambridge: Cambridge University Press, 2012).

40. Z. Maleeva, "Chego zhdut krest'iane ot zemel'nykh reform? [What do the peasants expect from land reform ?]," IGZK, no. 2-3 (1-15 avgusta, 1917) : 31.

41. V.I. Kostrikin, Zemel'nye komitety v 1917 godu [The land committees in 1917] (M. : Nauka, 1975).

42. See esp., GARF f.1796, op. 1, 1917, d. 24, Perepiska..., 3 iunia-23 sentiabria $1917 \mathrm{~g}$. [Correspondence..., 3 June-23 September 1917], 1. 83, 95, 99.

43. See Stenograficheskii otchet pervago s"ezda Zapadno-Sibirskago Soveta Krest'ianskikh Deputatov (zasedaniia 25-31 marta 1917 g.) [Stenographic report of the first congress of the Western Siberian Soviet of peasant deputies] (Omsk, 1917) for an illustration of such political beauty pageants.

44. Report of Samara branch of the Peasant Land Bank director, GARF f. 1797, op. 1, 1917, d. 135, Zhurnal Samarskii gubernskii, zemel'nyi komitet 19 iiulia $1917 \mathrm{~g}$. [Journal of the Samara provincial land committee, 19 July 1917], 1. 32.

45. Pravilova, A Public Empire, chpt. 3.

46. "Primernyi nakaz. Sostavlennyi na osnovanii 242 nakazov, dostavlennykh s mestnymi deputatami na II-oi Vserossiiskii s"ezd Sovetov krest'ianskikh deputatov v Petrograde v 1917 godu [The Model Mandate: Compiled on the basis of 242 mandates delivered by local deputies to the Second All-Russian Congress of Soviets of Peasant Deputies in Petrograd in 1917]," in A.V. Shestakov, ed., Sovety krest'ianskikh deputatov i drugie krest'ianskie organizatsii [Soviets of peasant deputies and other peasant organisations], T. 1, ch. I (Mart-Oktiabr' 1917 g.) (M. : Izd. Kommunisticheskoi Akademii, 1929) : 152-155.

47. For example Protokol zasedaniia vtorogo Gubernskago S"ezda Krest'ianskikh Deputatov Mogilevskoi gubernii ot 7-9 avgusta 1917 goda (no pub. info.) [Protocol of the meetings of the second provincial congress of peasant deputies of Mogilev province from 7-9 August 1917].

48. GARF, f. 1797, op. 1, 1917, d. 135, 1. 52-58, 75.

49. G.I. Baskin, "Proizvoditel'nost' zemledel'cheskago truda i chistaia dokhodnost' kho--ziaistva (po dannym Permskoi gubernii) [The productivity of agricultural labor ansd the net income of an economy (according to data from Perm' province)]," Narodnoe Khoziaistvo, kn.4 (1902) : 102-113; and his report to the land committee, Metod opredeleniia potrebitel'no-trudovykh zemel'nykh norm [The method of defining consumption-labor land norms] (Samara: Tip. Gub. Zemstva, 1917).

50. Baskin, Metod opredeleniia potrebitel'no-trudovykh zemel'nykh norm, 2-3.

51. GARF, f. 1797, op. 1, 1917, d. 135, 1. 75.

52. GARF, f. 1796, op. 1, 1917, d. 51, Protokoly Golovetsago Volost'nago Zemel'nago Komiteta 29 iiunia 1917 g. [Protocols of the Golovets Parish Land Committee 29 June, 1917], 1. 3.

53. GARF, f. 1796, op. 1, 1917, d. 51, Protokoly Semeikovskago Volost'nago Zemel'nago Komiteta 15 avgusta 1917 g. [Protocols of the Semeikovsk Parish Land Committee 15 August, 1917], 1. 33. 
54. GARF, f. 1796, op. 1, 1917, d. 51, Protokoly Veprevskago Volost'nago Zemel'nago Komiteta, 1. 9 [Protocols of the Veprevsk Parish Land Committee].

55. GARF, f. 1796, op. 1, 1917, d.51, Protokoly Sychevskago Volost'nago Zemel'nago Komiteta [Protocols of the Sychevsk Parish Land Committee], 1. 25.

56. GARF, f. 1796, op. 1, 1917, d. 58, Protokoly Mashevskago Volostnago Zemel'nago Komiteta 24 June $1917 \mathrm{~g}$. [Protocols of the Mashevsk Parish Land Committee 24 June, 1917], 1. 53-53ob ; GARF, f. 1796, op.1, 1917, d.59, Protokoly Andreevskago Volostnago Zemel'nago Komiteta 24 June 1917 g. [Protocols of the Andreevsk Parish Land Committee 24 June, 1917], 1. 6-7.

57. John Channon, "The Bolsheviks and the Peasantry: The Land Question in the First Eight Months of Soviet Rule," The Slavonic and East European Review, 66, 4 (1988) : 593-624 ; James Heinzen, Inventing a Soviet Countryside : State Power and the Transformation of Rural Russia, 1917-1929 (Pittsburgh : University of Pittsburgh Press, 2004).

58. P.N. Pershin, Agrarnaia revoliutsiia v Rossii, kn. 2, Agrarnye preobrazovaniia Velikoi Oktiabr 'skoi Sotsialisticheskoi Revoliutsii (1917-1918) [Agrarian revolution in Russia, book 2 : Agrarian transformations of the Great October Revolution (1917-1918)] (M. : Nauka, 1966), 257-258.

59. Dekrety sovetskoi vlasti, T. I. 25 oktiabria 1917 g.-16 marta 1918 g. [Decrees of Soviet power. T. I. 25 October 1917-16 March 1918] (M., 1957), 18-19.

60. Dekrety sovetskoi vlasti, T. I, 218-224.

61. Atkinson, The End of the Russian Land Commune, 173-175.

62. Pershin, Agrarnaia revoliutsiia v Rossii, 261; Atkinson, The End of the Russian Land Commune, 177-178.

63. Atkinson, The End of the Russian Land Commune, 182. See also Yaney, The Urge to Mobilize, 470-476, for a less positive assessment.

64. Dekrety sovetskoi vlasti, T. I, 408.

65. Paragraphs 5 and 6, Dekrety sovetskoi vlasti, T. I, 411-12.

66. Paragraph 14, Dekrety sovetskoi vlasti, T. I, 412-13.

67. Pershin, Agrarnaia revoliutsiia v Rossii, 262-6, 288. See also Atkinson, The End of the Russian Land Commune, chpt. 10 ; D.V. Kovalev, "Sotsializatsiia zemli i krest'ianskoe zemlepol'zovanie (po materialam Podmoskov'ia) [The socialization of the land and peasant land use (according to materials from the Moscow region]," Otechestvennaia istoriia, no. 5 (2007) : 97-106.

68. Retish, Russia's Peasants in Revolution and Civil War, 140-143.

69. N.F. Annenskii, "Zemskii kadastr i zemskaia statistika [Zemstvo cadaster and zemstvo statistics]," Trudy podsektsii statistiki IX s"ezda russkikh estestvoispitatelei i vrachei. Moskva 3-11 ianvaria 1894 goda [Proceedings of the statistical subsection of the IXth congress of Russian naturalists and doctors. Moscow, 3-11 January 1894] (Chernigov: Tip. Gub. Zemstva, 1894), 1-8 ; Catherine Evtuhov, Portrait of a Russian Province: Economy, Society and Civilization in Nineteenth-Century Nizhnii Novgorod (Pittsburgh : University of Pittsburgh Press, 2011) ; David Darrow, "The Politics of Numbers: Zemstvo Land Assessment and the Conceptualization of Russia's Rural Economy," The Russian Review, 59, no. 1 (2000) : 52-75.

70. Pershin, Agrarnaia revoliutsiia v Rossii, 268-270.

71. Pershin, Agrarnaia revoliutsiia v Rossii, 270-271.

72. Pershin, Agrarnaia revoliutsiia v Rossii, 288.

73. Holquist, "In Accord with State Interests," 173-174.

74. Jonathan D. Smele, Civil War in Siberia : The Anti-Bolshevik Government of Admiral Kolchak, 1918-1920 (Cambridge : Cambridge University Press, 1996), 280.

75. Peter Holquist, "A Russian Vendee: The Practice of Revolutionary Politics in the Don Countryside, 1917-1921" (Ph.D. diss., Columbia University, 1995), 599. This resentment had been brewing for well over a decade. See Duma debates on a proposal to address these grievances in Gosudarstvennaia Duma. Stenograficheskii otchet. Tretii sozyv, sessiia II, chast' I, zasedanie 
dvadtsat' vosmoe (8 dekabria 1908 g.) [State Duma. Stenographic report of the third calling, second session, part I, $28^{\text {th }}$ meeting (8 December 1908)] (SPb. : Gos. Tip., 1909), 3275-9.

76. Holquist, “A Russian Vendee," 602-612.

77. Peter Kenez, Civil War in South Russia, 1918: The First Year of the Volunteer Army (Berkeley : University of California Press, 1971), 196.

78. Peter Kenez, Civil War in South Russia, 1919-1920 (Berkeley : University of California Press, 1977), 80, 211.

79. M. Mal't, "Denikinshchina i krest'ianstvo [The time of Denikin and the peasantry]," Proletarskaia Revoliutsiia, no. 4 (1924) : 147.

80. Kenez, Civil War in South Russia, 1919-1920, 88.

81. Senator G. Glinka, "Untitled essay re Wrangel as reformer," typescript, n.d. (but after 25 April 1928), box 166, folder 24 (reel 217), HIA WC (Hoover Institution Archives, Wrangel Collection).

82. On Glinka, see Holquist, "In Accord with State Interests."

83. Kenez, Civil War in South Russia, 1919-1920, 281-282 ; Glinka, "Untitled essay re Wrangel as reformer," HIA WC, box 166, folder 24, 9.

84. Kenez, Civil War in South Russia, 1919-1920, 285-6 ; Glinka, "Untitled essay re Wrangel as reformer," HIA WC, box 166, folder 24, 10. Sevastopol' Peasant Soviet representatives evidently did not object to the project terms (though perhaps they were simply playing for time?).

85. Glinka, "Untitled essay re Wrangel as reformer," HIA WC, box 166, folder 24, 16.

86. Glinka, "Untitled essay re Wrangel as reformer," HIA WC, box 166, folder 24, 19, 21-22.

87. Glinka, "Untitled essay re Wrangel as reformer," HIA WC, box 166, folder 24,20 ; Glavnokomanduiushchago Vooruzhenymi Silami na Iuge Rossii, Prikaz o zemle, ot 20 maia 1920 goda. So vsemi dopolneniiami (Istanbul : "Za Rubezhom," n.d.), 5-6 [The Order on Land from 20 May 1920. With all supplementary materials].

88. Glinka, "Untitled essay re Wrangel as reformer," HIA WC, box 166, folder 24, 28, 31.

89. Glinka, "Untitled essay re Wrangel as reformer," HIA WC, box 166, folder 24, 25-26.

90. Glinka, "Untitled essay re Wrangel as reformer," HIA WC, box 66, folder 24, 26.

91. V.I.Gurko, Otryvochnyia mysli po agrarnomu voprosu [Fragmentary thoughts on the agrarian question] (SPb. ; Skoropech. P.O. Iablonskago, 1906), 24-28; David A.J. Macey, Government and Peasant in Russia, 1861-1906: The Prehistory of the Stolypin Reforms (DeKalb, IL : Northern Illinois University Press, 1987).

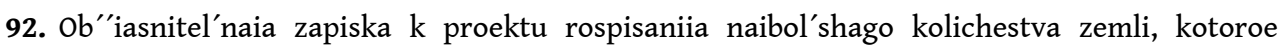
mozhet byt' priobreteno pri sodeistvii Krest'ianskago Pozemelnago Banka [Explanatory note to the draft schedule of the greatest amount of land that can be acquired with the assistance of the Peasant Land Bank] (SPb. : Pech. S.P. Iakovleva, 1900); Prikaz o Zemle, 4-5.

93. Glinka, "Untitled essay re Wrangel as reformer," HIA WC, box 166, folder 24, 28.

94. A.A. Rybnikov, $K$ postanovke agrarnago voprosa [Towards a formulation of the agrarian question] (Saratov : Tip. O-va Knigopechatnikov, 1917), 2-3.

95. V.V. Kabanov, Krest'ianskoe khoziaistvo v usloviiakh "voennogo kommunizma" [The peasant economy in the conditions of "war communism"] (M. : Nauka, 1988), 24. 


\section{ABSTRACTS}

Between 1861 and 1917 a "land allotment mentalité" developed among government officials, public activists and peasants themselves that shaped discussions of land reform in 1917 and the following years, representing a broad consensus on how social justice as it applied to land reform might be judged and measured. Based on the published and archival materials of the Main Land Committee, peasant congress publications, and the Hoover Institution Archive's Wrangel Collection this article examines discussions of land reform in the revolutionary period. It shows that from the Provisional Government's Main Land Committee down to peasant assemblies and ultimately both sides of the post-October Civil War the "norm" was understood as a fundamental moral and economic foundation for any new order.

Entre 1861 et 1917, le développement, chez les représentants du gouvernement, les activistes publics et les paysans eux-mêmes, d'une sorte de «mentalité de l'attribution des terres » façonna les discussions relatives à la réforme agraire, en 1917 et les années suivantes. Elle rassemblait un large consensus sur la façon dont la justice sociale, telle qu'appliquée à la réforme, pouvait être évaluée et mesurée. S'appuyant sur des sources publiées et des archives du Comité central agraire, des publications issues des congrès paysans et du fonds d'archives Wrangel de l'Institution Hoover, cet article étudie les discussions sur la réforme agraire pendant la période révolutionnaire. Il montre que dans toutes les strates - Comité central agraire du gouvernement provisoire, assemblées paysannes, ou belligérants de la guerre civile - la « norme » se comprenait comme le fondement moral et économique essentiel de tout nouvel ordre.

\section{AUTHOR}

\section{DAVID DARROW}

University of Dayton, Ohio, ddarrow1@udayton.edu 